\title{
A Study of the Efficiency of Futures Research Institutes of China*
}

\author{
Guo-Hua WU', Tian-Yin YAO², Bao-Ping ZHANG ${ }^{3}$ \\ Received: September 01, 2020 Revised: October 26, 2020 Accepted: November 05, 2020
}

\begin{abstract}
The purpose of this study is to analyze the efficiency of research institutes of futures companies, and to promote the development of futures market and real economy. This study employs DEA-solver software to conduct super-efficiency data envelopment analysis (SE-DEA), and also selects 40 representative futures research institutes in China as decision-making units (DMUs). For data of input and output indicators, we collect from the China Futures Association, Futures Daily, Hexun.com and Webstock.com respectively, and the time duration is the 103 trading days between from October 2019 to February 2020. Then the indicator for the strategy accuracy rate is calculated separately by analyzing the strategies published by each DMUs in public media. In conclusions, most institutes have excessive investment in human resources, and also have insufficient strategy accuracy rate and insufficient published research reports. The findings of this study suggest that Chinese futures companies need to improve the efficiency of research institutes, and better meet the demand of the financial market. In fact, the analysis of the efficiency of the futures company research institute has not been found in the literature worldwide, Application of DEA model in efficiency analysis of securities and futures research institutions and establishment of indicators are the innovations of this paper.
\end{abstract}

Keywords: Futures, Research Institute, Efficiency, Data Envelopment Analysis

JEL Classification Code: G14, G24, P43

\section{Introduction}

The opening of the Zhengzhou Grain Wholesale Market in October 1990, the first pilot market for futures trading in China, marked the official beginning of the Chinese futures

\footnotetext{
*Acknowledgments:

[1] We thank Ms. Shan-Shan Cong and Ms. Min Li (the Institute of Huishang Futures Co., Ltd.) for helping to sort out some of the data. [2] We thank Changjiang Scholar Program Candidate, Professor Xinbao Liu (School of Management, Hefei University of Technology) for his important advice and guidance.

${ }^{1}$ First Author and Corresponding Author. [1] Senior Economist, Postdoctoral Advisor, School of Management, Hefei University of Technology, China [2] Chairman, Huishang Futures Co. Ltd., China [Postal Address: No.258, Wuhu Road, Hefei, Anhui 230061, P. R. China] Email: 985861543@qq.com

${ }^{2}$ Researcher, Huishang Futures Co. Ltd., China.

Email: yaotianyin@yahoo.com.au

${ }^{3}$ Institute Director, Huishang Futures Co. Ltd., China.

Email: Zhangbp@hsqh.net

(c) Copyright: The Author(s)

This is an Open Access article distributed under the terms of the Creative Commons Attribution Non-Commercial License (https://creativecommons.org/licenses/by-nc/4.0/) which permits unrestricted non-commercial use, distribution, and reproduction in any medium, provided the original work is properly cited.
}

market. In May 2014, the State Council issued several opinions on further promoting the healthy development of capital markets, and the futures industry entered a new stage of innovative development. Over the past 30 years, China's futures market has experienced four stages: initial establishment, rectification, standardized development and innovative development. In recent years, the development of China's futures industry has gradually accelerated, and special futures law is about to be introduced. The futures market features continuous growth in listed varieties and risk management tools, and the real economy for futures services is developing in depth. Stock index futures are gradually being consolidated in fewer exchanges, and their trading is normalized. Stock index options are successfully traded on the market. Banks and institutions are also expressing interest in treasury bond futures. The increasing number of international varieties and commodity options further expand the set of available risk management tools, giving firms more tools to manage market price risks in the course of business operations. The removal on the limit on the proportion of foreign shares held by futures companies will become a reality later this year. The futures market has shown a trend toward vigorous development in both scale and quality. 
The futures research institutes of China have also made progress in exploring the sector's development, especially in the initial stage. Due to the small number of futures listed, the small market size, the large number of futures companies, and the poor profitability of these companies, some futures companies experience a cycle of establishment, withdrawal, re-establishment and re-withdrawal to develop futures research institutes. Moreover, some futures companies that establish research institutes and then turn them into business units. Some futures companies have set research objectives and explored research methods to achieve substantial gains. While continuing the operations of their research institutes, these firms also gradually transferred talent to departments and positions such as private equity funds, asset management and investment managers.

Lee (2020) stated that research and development investment has a stable and strong positive impact on the enterprise market value of China's listed manufacturing companies, meanwhile, the impact has time lag. The result of an efficiency analysis of research and development investments by Chinese futures companies are a strong proof of the above Lee's research results in the futures industry.

Jiang (2018) pointed out: "There are 1.287 million investors in China's futures market who opened accounts; $97 \%$ of them are natural person customers representing $46 \%$ of capital, and $3 \%$ of are legal person customers representing $54 \%$ of capital, while more than $70 \%$ of customers in mature Western futures markets are institutional investors. In the US, individual investors represent less than $10 \%$ of the market." This market structure, with individual investors representing the bulk of the market, entails greater requirements in conducting futures research. Thus, an analysis of the efficiency of futures research has great practical significance as well as theoretical value.

\section{Literature Review}

Some scholars have studied the efficiency of insurance institutions, banks, securities and futures markets. Yao, Feng and Han (2005) used the DEA method to measure the efficiency of 22 insurance institutions in China from 1999 to 2020. Recently, Feng (2019) focused on what changes internet finance imposed on domestic commercial banks and used the DEA method to analyze the efficiency of commercial banks that chose internet financial strategies. Based on the levels of mobile payments, online loans, and online banking services, he stated that internet finance had already become an important way to optimize the efficiency of domestic commercial banks. Le (2020) represented that DEA estimation to measure the effectiveness of retail banking activities, the rating result shows the branches in An Giang, Can Tho, Dong Thap, Kien Giang, Long An, Phu Quoc and Tra Noc rank at the top technical efficiency.
By employing the Data Envelopment Analysis (DEA) method, Banna, Ahmad and Koh (2020) stated that crisis along with bank size, capital adequacy ratio, return on average equity and real interest rate have a significant effect on bank efficiency in Bangladesh, after Banna et al. (20020) computed the technical efficiency of individual banks operating in Bangladesh banking sector during 2000 to 2013.

Ouyang (2005) proposed a framework for analysing the efficiency of the futures market, dividing the efficiency of the futures market into micro-efficiency and macroefficiency. Micro-efficiency includes structural efficiency, allocation efficiency, operational efficiency and system innovation efficiency. Macro-efficiency consists of three main indicators: the dependence of economic operations of the futures market, the adaptability of the futures system to other economic systems, and the effect of the futures market on macroeconomic stability. The efficiency of futures research institutes should be part of micro-efficiency. Chen and Zheng (2008) held that futures market efficiency includes pricing efficiency and information efficiency. Only a futures market with effective pricing can give full play to the functions of price discovery and risk management. We believe that the realization of pricing efficiency and information efficiency is closely related to the performance of futures research institutes.

Some scholars have studied the efficiency of institutions of higher learning. Ni (2016) noted that data envelopment analysis (DEA) is an important method for modelling the efficiency of scientific research conducted at colleges and universities. Luo and Guo (2011) used the model to evaluate the scientific research efficiency of 36 universities involved in "the 985 Project" in China, and the feasibility and effectiveness of the empirical model were verified by a comparative verification method. For example, Zhang, Zhang and Luo (2013) used the DEA method to analyze the scientific research performance of local universities in 31 provinces and cities in China in 2011 and concluded that the overall efficiency of resource allocation in local universities in all provinces was low. Zhang and Zhang (2015) applied the DEA model to analyze the efficiency of scientific research and innovation in 31 provinces and cities in China in 2011. They concluded that there were significant differences in efficiency levels across the three economic zones in the East, Central and Western regions. Nine provinces and cities in China achieved relative efficiency optimization, while the remaining provinces and cities still had room for improvement. Further refinements to efficiency analysis have also been made to comprehensively analyze the efficiency changes from static and dynamic perspectives and account for the influence of lags to match input and output (Yan, Ma, \& Wang, 2016).

In addition, Sathye (2003) used the DEA method to conduct empirical research on the efficiency of Indian banks. 
According to the results, the average performance efficiency of Indian banks was higher than the world average, but their efficiency in capital scale, branch networks, and labour cost was lacking. Sathye suggested that Indian banks should reduce their capital input and size of branch networks to further improve their performance efficiency. Wang and Cheng (2009) used the DEA method to measure the efficiency of 32 securities companies in China from 2004 to 2006. They found that many Chinese securities companies exhibited poor performance efficiency and decreasing returns to scale; the main reason for these results was technical change. Zhang, Zhang and Luo (2006) used the DEA method to conduct empirical research on the efficiency of US securities firms from 1980 to 2000. Regarding research methods, the BCC and the CCR models are chosen to study the technical efficiency, scale efficiency and pure technical efficiency of American securities firms. Based on the efficient market hypothesis and new institutional economics.

However, thus far, almost no research has been conducted on the input-output efficiency of the research institutes of futures companies in either the Chinese or international literature. This paper is the first one to use a DEA model for the analysis of the efficiency of futures research institutes. In addition, we advance some new policy recommendations. We believe that these analysis and discussions will make corresponding contributions to the improvement of the efficiency of futures research institutes, the development of futures research and the futures industry at home and abroad, and innovation and development concerning how futures can serve financial markets and the real economy.

\section{Research Method}

In this paper, data envelopment analysis (DEA) is used to analyze the input-output efficiency of futures research institutes using data on the number of investment research reports and investment strategies published by the three major authoritative media outlets in the domestic futures industry and data published by the China Futures Association.

\subsection{Model Design}

DEA (data envelopment analysis) is based on the principle of holding the input or output of decision-making units (DMUs) unchanged to determine the relative effective production efficiency frontier through mathematical programming and statistical analysis. Each decision-making unit is projected onto the DEA frontier, and the relative efficiency is then assessed by comparing the extent to which decision-making units deviate from the DEA frontier. The DEA method has many advantages in the comprehensive evaluation of the effectiveness of multi-input, multioutput systems. This is mainly because it does not directly perform dimensionless processing or impose any weighting assumption. It excludes subjective factors and is highly objective. In addition, the DEA method assumes that each input indicator is related to one or more output indicators and that there is some connection between them, but it is not necessary to determine the expression for this connection. When the DEA method is applied, the CCR model can be used to judge whether a unit has both technical efficiency and scale efficiency, while the BCC model can be used to judge whether it has pure technical efficiency and perform slack variable analysis.

\subsection{Indicator Selection}

The research activities of the research institutes of Chinese futures companies can be represented as a complex system of multivariable inputs and outputs, and the selection of the system of evaluation indicators is the key factor related to the scientific validity, fairness and rationality of suggestions made in the evaluation of the efficiency of the research institutes of Chinese futures companies. Therefore, it is important to establish a scientific system of indicators. Guan (2009) divided scientific research activities into input and output. His input variables included scientific researchers and scientific research funds. He reported that the scientific research equipment variable had difficulty passing the significance test and was not taken as an input variable. His output variables included the ability to develop scientific and technological productivity, including highquality scientific papers, important intellectual property rights, important consulting reports, important scientific and technological awards, and the completion of strategic scientific and technological tasks.

Gui and Zhang (2016) emphasized that the selection of indicators should follow the principles of authenticity and operability; thus, they argued that R\&D funds and R\&D personnel should be taken as input indicators and that the numbers of academic papers, patent applications and academic works should be taken as output indicators. Yang and Yang (2011) used the DEA method for the analysis of the scientific and technological input and output efficiency of 10 tea research institutes above the provincial level in China from 2006 to 2010. The scientific and technological input, personnel input and per capita input were taken as the scientific and technological input indicators. The scientific and technological output indicators mainly included five categories: published papers, published monographs, awards, authorized patents and variety identification.

Bian and Chen (2009), in their analysis of the operating efficiency of China's securities firms, employed wages, benefits and expenses as input indicators. Fukuyama and Weber (1999) used DEA and Malmquist methods to measure production efficiency and cost efficiency when studying the 
operating efficiency of Japan's securities firms from 1993 to 1997 , taking the labour and departmental expenses of the four securities firms as important indicators. According to the Cobb-Douglas production function, which is widely used in practice, $\mathrm{Q}=\mathrm{AL}^{\alpha} \mathrm{K}^{\beta}$, where $\mathrm{L}$ and $\mathrm{K}$ represent labour and capital, respectively; these are two important indicators for efficiency analysis. The main indicators for the development of the scientific and technological productivity and investment capability of the futures research institutes are investment strategy and investment research reports. Although some futures research institutes sometimes engage in major customer maintenance, futures training, participation or hosting of futures competitions, etc., these are not indicators of the scientific and technological productivity of the futures research institutes and therefore are not used as output indicators. Of course, these factors do influence the input-output efficiency of the research institutes.

At present, there is almost no regular expenditure on research projects except for the salaries of researchers. Personnel are the human resource input of the state and enterprises. Therefore, this paper divides the input indicator into labour input and department cost input, which consists mainly of all the personnel cost input that belongs to the company's research department. Output indicators mainly include research reports and investment strategies published by the above personnel in all public mainstream media. $\mathrm{Li}$, $\mathrm{Cao}$ and $\mathrm{Xu}$ (2004) stated that the investments in stocks and futures are highly complex, and investors need to have sufficient professional knowledge and a satisfactory investment strategy; otherwise, losses will be common. Luo (2015) insisted that a good futures investment strategy is the principal foundation of stable income generation, especially for private equity pursuing a speculative strategy, fund management and risk control. Li (1998) considered that investment strategy is also important even for hedgers. Yuan (2006) stated that stock investment strategy determines whether one's investment decisions are right or wrong.

Based on grey system theory and traditional technological analysis, he constructed a comprehensive stock and futures investment strategy and verified its validity. In summary, investment strategy can be chosen as an output indicator. In scientifically constructing the indicators considered here, not only do we include the investment consulting department personnel of each target company in the research department, but we also consider the quantity and indicators of output results to avoid ignoring quality and pursuing only the exposure rate and quantity. In addition, the DEA method requires that the number of indicators selected should be appropriate, and too many indicators will increase the effectiveness coefficient of a single decision factor until it approaches 1 . Therefore, it is not the case that the greater the number of indicators, the more aligned the interpretation of the model is with reality, in fact just the opposite. According to Cooper, $\mathrm{Gu}$ and $\mathrm{Li}$ (2001), the number of decision factors should satisfy $n \geq \max \{m X s, 3(m+s)\}$, where $n$ represents the number of decision factors, and $\mathrm{m}$ and $\mathrm{s}$ represent the number of input and output indicators, respectively. Finally, when selecting indicators, the rationality and validity of the data sources of the indicators should also be considered.

Based on the above analysis, the system of input-output indicators of the research departments of Chinese futures companies in this paper is shown in Table 1:

\subsection{Data Sources}

At present, there are 149 futures companies registered by the China Futures Association nationwide. As the DEA method is used for the analysis of the same type of decision-making units, this paper screens futures companies registered by the China Futures Association. The screening method is to count the number of companies that published research reports in three major media outlets, Futures Daily, Hexun.com and Webstock.com, during the 103 trading days from October 2019 to February 2020. Then we select the companies that published in at least two of these outlets and have a total number of reports greater than or equal to the average (10 articles). The indicator for the strategy accuracy rate is calculated separately by collecting the strategies published by each company in public media. Ultimately, 40 futures companies that meet the selection criteria are taken as the research objects. The statistical data for the indicator for human resources come from researchers of various futures companies publicized by the China Futures Association and are counted according to their subordinate departments.

Table 1: System of Input-output Indicators of Research Departments of Chinese Futures Companies

\begin{tabular}{|c|c|c|c|}
\hline & Projects & Indicators & Unit \\
\hline \multirow{2}{*}{$\begin{array}{l}\text { Input } \\
\text { indicator }\end{array}$} & Human resources & X1: Total Number of Research and Investment Advisory Departments & person \\
\hline & $\begin{array}{l}\text { Departmental } \\
\text { funds }\end{array}$ & X2: Annual Departmental Funds Input & $\begin{array}{l}\text { ten thousand } \\
\text { yuan }\end{array}$ \\
\hline \multirow{2}{*}{$\begin{array}{l}\text { Output } \\
\text { indicator }\end{array}$} & Research report & Y1: Number of Research Reports Published in the Mainstream Media & article \\
\hline & $\begin{array}{l}\text { Accuracy of } \\
\text { strategy }\end{array}$ & Y2: Accuracy Rate of Public Media Strategies & percentage \\
\hline
\end{tabular}




\section{Empirical Results}

This paper uses DEA software and CCR, BCC and superefficiency models for the analysis of the input-output data of 40 futures companies in 2019.

\subsection{Descriptive Analysis}

Through the primary data analysis, this paper finds that the input-output data of our 40 futures companies exhibit the following summary statistics:

(1) Regarding the number of companies that have published research reports in the three major media outlets, the average is 33.72 , the standard deviation is 25.98 , and the maximum and minimum are 119 and 10 , respectively.

(2) The average number of investment strategies published are 283, the standard deviation is 206, and the maximum and minimum are 720 and 29, respectively.

(3) Regarding the investment strategy accuracy rate, the average is 0.699 , the standard deviation is 0.079 , and the maximum and minimum are 0.91 and 0.52 , respectively.

(4) The average labour cost is 15,141 per month, the standard deviation is 22,949 , and the maximum and minimum are 13,000 and 6000 , respectively.

\subsection{Comprehensive Analysis}

The results are shown in Table 2.

First, from the perspective of comprehensive efficiency, the 40 futures companies scored a maximum of 1 , a minimum of 0.095 and an average of 0.395 , which shows that there is a large gap in efficiency between the research institutes of futures companies. Specifically, the DEA revealed 3 companies with the best efficiency, namely, Jinshi Futures, Dayou Futures and BOC International Futures, which account for $7.5 \%$ of the research objects. These three companies are also effective in pure technical efficiency and scale efficiency, which shows that they have the right inputoutput ratios for their research institutes, have fully utilized the labour and costs invested and have achieved the maximum output results at this input level. If these futures companies want to increase their output, they can only separately or simultaneously increase the input of department personnel or funds; otherwise, the existing output cannot be increased. Because the returns to scale are constant, the output will increase by one unit for each additional unit of input.

By comparing the input-output data, it is found that the three companies do not invest the most in their research departments. In contrast, Jinshi Futures, Dayou Futures and BOC International Futures all exhibit an overall balance between scientific research personnel and funding input. Dayou Futures ranks last in personnel and funding input, but its overall output is optimal; that is, it has achieved high output for low input. In addition, the investment of
Donghai Futures is consistent in the middle and upper rankings of the 40 futures companies, its overall efficiency ranking is always in the middle and upper positions, but its investment is not the highest. The above analysis shows that the scientific research input and output of futures companies that are DEA-efficient are equivalent to their scale. There are 37 companies that are not efficient according to the DEA, accounting for $92.5 \%$ of the sample. Among them, there are 5 companies that are slightly inefficient and 32 companies that are seriously inefficient, accounting for $12.5 \%$ and $80 \%$ of the sample, respectively. This shows that the efficiency level of the research institutes of futures companies is generally low, and a large number of research institutes have not achieved comprehensive efficiency and effectiveness.

From the perspective of pure technical efficiency, the maximum value is 1 , the minimum value is 0.099 , and the average value is 0.468 . There are 7 company research institutes with efficient technical efficiency, accounting for $17.5 \%$ of the sample. Apart from the above 3 companies, China Futures, Lu Zheng Futures, Changjiang River Futures and Guoyuan Futures are also efficient in terms of comprehensive efficiency. These companies have invested reasonable resources in their research departments. They are inefficient in terms of comprehensive efficiency but efficient in pure technical efficiency, which means that the main reason that the DEA scores them as inefficient their inefficiency in scale efficiency. As seen from Table 2, the research departments of the above four futures companies exhibit diminishing returns to scale, which should be addressed.

There are 33 research institutes with poor technical efficiency, accounting for $82.5 \%$ of the sample and indicating that the allocation of research department resources by futures companies requires further improvement. From the perspective of scale efficiency, the maximum value is 1 , the minimum value is 0.356 , and the average value is 0.876 . All decision-making units with poor DEA evaluations also have poor scale efficiency. The inefficient comprehensive efficiency of research departments is attributable to pure technical efficiency and scale efficiency. In terms of returns to scale, 14 research institutes have constant returns to scale, accounting for $35 \%$ of the sample, and the returns are economic. There are 7 futures companies with increasing returns to scale, accounting for $17.5 \%$ of the sample, including Baocheng Futures, Qianhai Futures and Zhonghui Futures. This shows that these futures companies have invested insufficiently in research departments. Increasing personnel and funding will increase output disproportionately highly. There are 19 companies with diminishing returns to scale, accounting for $47.5 \%$ of the sample, including Changjiang Futures, among others. These companies generally have the problem of relatively excessive investment in research department resources, which should be appropriately reduced. All cases of diminishing returns to scale here are observed in those companies with banking or securities 
Table 2: System of Input-output Indicators of Research Departments of Chinese Futures Companies

\begin{tabular}{|c|c|c|c|c|c|c|}
\hline DMU & Rank & $\begin{array}{c}\text { Super } \\
\text { efficiency }\end{array}$ & $\begin{array}{c}\text { Overall } \\
\text { efficiency }\end{array}$ & $\begin{array}{c}\text { Pure technical } \\
\text { efficiency }\end{array}$ & $\begin{array}{c}\text { Scale } \\
\text { efficiency }\end{array}$ & $\begin{array}{c}\text { Returns to } \\
\text { scale }\end{array}$ \\
\hline Jinshi Futures & 1 & 2.567 & 1 & 1 & 1 & Constant \\
\hline There are Plenty of Futures & 1 & 1.14 & 1 & 1 & 1 & Constant \\
\hline BOC International Futures & 1 & 1.112 & 1 & 1 & 1 & Constant \\
\hline Guoyuan Futures & 4 & 0.938 & 0.938 & 1 & 0.938 & Decreasing \\
\hline Chang-an Futures & 5 & 0.932 & 0.932 & 0.988 & 0.943 & Decreasing \\
\hline Ning Zheng Futures & 6 & 0.869 & 0.869 & 0.875 & 0.993 & Constant \\
\hline Chang Jiang Futures & 7 & 0.821 & 0.821 & 1 & 0.821 & Decreasing \\
\hline Zhongyuan Futures & 8 & 0.732 & 0.732 & 0.743 & 0.985 & Constant \\
\hline Funeng Futures & 9 & 0.554 & 0.554 & 0.716 & 0.774 & Decreasing \\
\hline Jinrui Futures & 10 & 0.483 & 0.483 & 0.568 & 0.850 & Decreasing \\
\hline Bao Cheng Futures & 11 & 0.46 & 0.46 & 0.488 & 0.943 & Increasing \\
\hline China Futures & 12 & 0.432 & 0.432 & 1 & 0.432 & Decreasing \\
\hline Gelindahua Futures & 13 & 0.411 & 0.411 & 0.433 & 0.949 & Decreasing \\
\hline China International Futures & 14 & 0.38 & 0.38 & 0.521 & 0.729 & Constant \\
\hline Qianhai Futures & 15 & 0.37 & 0.37 & 0.387 & 0.956 & Increasing \\
\hline Lu Zheng Futures & 16 & 0.356 & 0.356 & 1 & 0.356 & Decreasing \\
\hline Rida Futures & 17 & 0.348 & 0.348 & 0.434 & 0.802 & Constant \\
\hline Hongyuan Futures & 18 & 0.298 & 0.298 & 0.34 & 0.876 & Constant \\
\hline Donghai Futures & 19 & 0.285 & 0.285 & 0.327 & 0.872 & Constant \\
\hline Zhong Hui Futures & 20 & 0.284 & 0.284 & 0.345 & 0.823 & Increasing \\
\hline First Futures & 21 & 0.274 & 0.274 & 0.286 & 0.958 & Decreasing \\
\hline Guosen Futures & 22 & 0.271 & 0.271 & 0.552 & 0.491 & Decreasing \\
\hline Shen Yin \& Wanguo Futures & 23 & 0.271 & 0.271 & 0.299 & 0.906 & Increasing \\
\hline Holly Futures & 24 & 0.266 & 0.266 & 0.298 & 0.893 & Constant \\
\hline Haitong Futures & 25 & 0.264 & 0.264 & 0.266 & 0.992 & Decreasing \\
\hline Everbright Futures & 26 & 0.218 & 0.218 & 0.228 & 0.956 & Decreasing \\
\hline Guangzhou Futures & 27 & 0.216 & 0.216 & 0.236 & 0.915 & Constant \\
\hline Xinhua Futures & 28 & 0.213 & 0.213 & 0.373 & 0.571 & Decreasing \\
\hline Cinda Futures & 29 & 0.212 & 0.212 & 0.243 & 0.872 & Constant \\
\hline Zhaojin Futures & 30 & 0.197 & 0.197 & 0.222 & 0.887 & Increasing \\
\hline Hui Shang Futures & 31 & 0.187 & 0.187 & 0.203 & 0.921 & Decreasing \\
\hline SDIC Essence Futures & 32 & 0.185 & 0.185 & 0.195 & 0.949 & Constant \\
\hline Founder CIFCO Futures & 33 & 0.181 & 0.181 & 0.203 & 0.892 & Constant \\
\hline Guangfa Futures & 34 & 0.175 & 0.175 & 0.183 & 0.956 & Decreasing \\
\hline Zheshang Futures & 35 & 0.159 & 0.159 & 0.168 & 0.946 & Decreasing \\
\hline Guotai Junan Futures & 36 & 0.146 & 0.146 & 0.147 & 0.993 & Increasing \\
\hline Nanhua Futures & 37 & 0.128 & 0.128 & 0.137 & 0.934 & Decreasing \\
\hline Citic Futures & 38 & 0.101 & 0.101 & 0.102 & 0.990 & Increasing \\
\hline Yongan Futures & 39 & 0.099 & 0.099 & 0.099 & 1 & Decreasing \\
\hline Huatai Futures & 40 & 0.095 & 0.095 & 0.099 & 0.960 & Decreasing \\
\hline
\end{tabular}


brokerage backgrounds or with a high market share in the industry. Given their considerable background, greater businesses and larger market scale, too much investment leads to a relative surplus of resource inputs.

For example, Huatai, Yong'an, Zhongxing, Nanhua, Guotaijun'an, and Zheshang Futures, despite being famous, outstanding companies with good operational indicators and large market shares, still rank poorly on efficiency according to our futures research institutes model because they devote considerable human and capital resources to research. Research creates value, and science and technology are productive forces. Input is a significant factor in the development of futures companies and helps them achieve the goals of transforming and upgrading and maintaining a better position in the industry than their competitors.

\subsection{Projection Analysis of Input and Output of Research Departments of Non-DEA Efficient Futures Companies}

To explore ways to improve the input-output efficiency of futures companies that the DEA regards as lacking in technical efficiency, this paper conducts a projection analysis for them and obtains the input redundancy and output insufficiency of 33 non-technical efficient companies (see Table 3 for details). Taking Founder CIFCO Futures as an example, its redundant funds are equal to 180,800 yuan, and the strategy accuracy rate is $6.07 \%$.

As shown in Table 3, 84.85\% of companies revealed a lack of technical efficiency by the DEA analysis exhibit input redundancy, of which 17 are redundant in human resources, accounting for $51.52 \%$ of the total. There are 11 companies with redundant scientific research expenditures, accounting for $33.33 \%$ of the total. It can be seen that most companies have different degrees of redundancy in their research department inputs, and excessive investment in human resources is common. Companies can improve the efficiency of their resource allocation by reducing investment in the personnel and funds of relevant departments. In terms of output, 25 companies have insufficient output from research departments, of which 11 are insufficient in published research reports, accounting for $44 \%$ of the total, and 16 are insufficient in the strategy accuracy rate, accounting for $64 \%$ of the total, with an average shortfall of $7.19 \%$. It can be seen that most companies have an insufficient strategy accuracy rate and insufficient published research reports, which shows that it is common for research departments to be seriously lacking in terms of transforming research into quality results. In summary, the allocation of resources by futures companies to their research departments need to be optimized, the inefficient allocation of personnel and funds urgently needs to be addressed, and the quality of research and the transformation of results need to be further strengthened.
Table 3: Input Redundancy and Output Shortfall in Research Departments of 33 Chinese Futures Companies in 2019

\begin{tabular}{|c|c|c|c|c|}
\hline \multirow{2}{*}{ DMU } & \multicolumn{2}{|c|}{ Input redundancy } & \multicolumn{2}{|c|}{ Output shortfall } \\
\hline & $\mathrm{X} 1$ & $\mathrm{X} 2$ & Y1 & Y2 \\
\hline $\begin{array}{l}\text { Baocheng } \\
\text { Futures }\end{array}$ & 0.5 & & & $5.12 \%$ \\
\hline $\begin{array}{l}\text { Qianhai } \\
\text { Futures }\end{array}$ & 0.05 & & & $3.86 \%$ \\
\hline $\begin{array}{l}\text { Founder } \\
\text { CIFO Futures }\end{array}$ & & 18.08 & & $6.07 \%$ \\
\hline $\begin{array}{l}\text { Shen Yin } \\
\& \text { Wanguo } \\
\text { Futures }\end{array}$ & & 26.65 & & $4.93 \%$ \\
\hline $\begin{array}{l}\text { SDIC } \\
\text { Essence } \\
\text { Futures }\end{array}$ & 2.36 & & & $4.08 \%$ \\
\hline $\begin{array}{l}\text { Guotai Junan } \\
\text { Futures }\end{array}$ & & 6.36 & & \\
\hline $\begin{array}{l}\text { Ruida } \\
\text { Futures }\end{array}$ & & 36.6 & & $12.5 \%$ \\
\hline $\begin{array}{l}\text { Donghai } \\
\text { Futures }\end{array}$ & & 26.14 & & $5.85 \%$ \\
\hline $\begin{array}{l}\text { Huishang } \\
\text { Futures }\end{array}$ & 0.8 & & & \\
\hline $\begin{array}{l}\text { Changan } \\
\text { Futures }\end{array}$ & & & & \\
\hline Holly Futures & 2.66 & & & $8.14 \%$ \\
\hline $\begin{array}{l}\text { Xinhu } \\
\text { Futures }\end{array}$ & 0.24 & & & \\
\hline $\begin{array}{l}\text { Zhongyuan } \\
\text { Futures }\end{array}$ & 1 & & & $1.19 \%$ \\
\hline First Futures & 0.07 & & & \\
\hline $\begin{array}{l}\text { CITIC } \\
\text { Futures }\end{array}$ & & 41.34 & & $16.7 \%$ \\
\hline $\begin{array}{l}\text { Guangfa } \\
\text { Futures }\end{array}$ & & & 2.55 & \\
\hline $\begin{array}{l}\text { Guangzhou } \\
\text { Futures }\end{array}$ & 0.12 & & & $6.27 \%$ \\
\hline $\begin{array}{l}\text { Zhong Hui } \\
\text { Futures }\end{array}$ & & 0.79 & & $12.6 \%$ \\
\hline $\begin{array}{l}\text { Haitong } \\
\text { Futures }\end{array}$ & 0.65 & & & \\
\hline $\begin{array}{l}\text { CITIC } \\
\text { Futures }\end{array}$ & & 4.54 & & \\
\hline $\begin{array}{l}\text { Yongan } \\
\text { Futures }\end{array}$ & 1.88 & & & \\
\hline
\end{tabular}


Table 3: Continued

\begin{tabular}{|l|l|l|l|l|}
\hline $\begin{array}{l}\text { Cinda } \\
\text { Futures }\end{array}$ & & 19.31 & & $6.55 \%$ \\
\hline $\begin{array}{l}\text { Guosen } \\
\text { Futures }\end{array}$ & & 70.26 & 7.17 & \\
\hline $\begin{array}{l}\text { Zheshang } \\
\text { Futures }\end{array}$ & 0.68 & & 5.47 & \\
\hline $\begin{array}{l}\text { Ning Zheng } \\
\text { Futures }\end{array}$ & 0.38 & & & $4.59 \%$ \\
\hline $\begin{array}{l}\text { Huatai } \\
\text { Futures }\end{array}$ & & & 5.25 & \\
\hline $\begin{array}{l}\text { Fuyuan } \\
\text { Futures }\end{array}$ & 0.92 & & 17.59 & \\
\hline $\begin{array}{l}\text { Hongyuan } \\
\text { Futures }\end{array}$ & 0.42 & & 3 & $8.34 \%$ \\
\hline $\begin{array}{l}\text { Zhaojin } \\
\text { Futures }\end{array}$ & & & 0.86 & $8.21 \%$ \\
\hline Jinrui Futures & 0.37 & & 21.07 & \\
\hline $\begin{array}{l}\text { Everbright } \\
\text { Futures }\end{array}$ & 0.27 & & 11.16 & \\
\hline $\begin{array}{l}\text { Gelin Dahua } \\
\text { Futures }\end{array}$ & & 8.6 & 8.67 & \\
\hline $\begin{array}{l}\text { Nanhua } \\
\text { Futures }\end{array}$ & & & & \\
\hline
\end{tabular}

\section{Discussion}

Studies have shown that the benefit of investing one dollar in scientific research is much greater than that of investing in expanded reproduction. Lee (2020) research indicates that corporate social responsibility activities have a strong positive impact on the company's market value, but the time lag also occurs. Futures companies invest in research and development for the purpose of better serving the society and investors, which is in essence the embodiment of corporate social responsibility. Although the Chinese futures company which invested the most in R\&D are not the most efficient, these two features prove the correctness of Lee's research conclusion. Therefore, futures companies still need to increase their investment in research. However, we should also emphasize the analysis of the efficiency of resource allocation in research departments and improve their investment and research management capabilities.

Futures companies that have highly efficient research but lack inputs should increase human and capital resources and obtain more research input, especially companies with a low rank and a lack of inputs. For example, they should consider implementing total value management. The accuracy rate of investment strategies published by the research institutes, the number of investment strategies multiplied by the accuracy rate, the number of investment and research reports multiplied by the value created and the number of times they are used by clients, and the application effect are calculated in economic terms. The evaluation is carried out according to the value created by researchers, and the evaluation results are related to personal salary and promotion.

Futures companies that have input redundancy, insufficient output, low efficiency, and decreasing scale efficiency should strengthen their research departments. To do so, they could, for example, establish input-output evaluation systems and conduct regular evaluations to strengthen the sense of responsibility among their personnel. They could establish incentive policies conducive to the transformation of high-quality research results in a standardized and planned way, strengthen the financial oversight of departmental funds, implement an effective cost accounting system. Further options include the implementation of fullvalue management and investment strategies to promote the accuracy of output in terms of the number of accurate investment strategies based on value calculations for the number of research reports and the number of customers who use them. Moreover, economic value should be accounted for separately based on calculations of the value created by researchers, with the assessment results being used as criteria in determining individual pay and promotions.

Futures companies should increase the income of their researchers because expanding the income gap between researchers and other ordinary management personnel would improve enthusiasm for research and development activities and the participation of senior talent in such efforts; this gap should be recognizable to other enterprises and industries and even society as a whole and form a social atmosphere.

Government departments of science and technology should attach more importance to futures research institutes, encourage and publicize scientific and technological awards, scientific and technological innovation, the establishment of postdoctoral workstations, the transformation of scientific research achievements, patents and intellectual property applications, etc. They should strengthen the horizontal contact between futures research institutes and relevant departments such as at universities, the Development Revolution Committee, Scientific and Technological Committee, etc., and set up a platform for scientific and technological innovations for universities, futures companies and relevant government departments.

This paper starts the first step of efficiency analysis of the research institutions of domestic and foreign futures companies. It is expected that more experts will use more research methods to analyze and study the research institutions of futures companies in the future, so as to promote the steady and rapid development of the futures 
market and lay a better infrastructure for price discovery and risk management of the market economy.

\section{Conclusion}

It's hard to start. Since there is no research on the efficiency of the Institute of Securities and Futures Companies at home and abroad so far, all of this paper is an attempt, and there is no previous experience to learn from.

Among the 40 futures companies registered by the China Futures Association, 7.5\% have research departments that exhibit efficiency, and $92.5 \%$ have not reached the efficient level. A considerable number of companies still have problems in the management of their research institutes, such as poor managerial skill and unreasonable resource allocations. The projection analysis of the input and output of research departments deemed technically inefficient by the DEA analysis revealed that $84.85 \%$ of these institutes have redundant input and that overinvestment in human resources is common. Most of these companies lacking in technical efficiency have insufficient output, particularly in terms of investment research reports and strategy accuracy rates. The allocation of resources in research departments needs to be optimized to avoid inefficient allocation of personnel and funds, while the quality of research and the transformation of results need to be further strengthened. The improvement of research department efficiency results from increases in the amount of research and efficiency of the personnel. All companies should continue to pay attention to increasing the amount of research and efficiency and strengthen relevant research innovation so that research results will be transformed and steadily improved so that there is an increase in the amount and efficiency of research.

\section{References}

Banna, H., Ahmad, R., \& Koh, H. Y. E. (2020). Determinants of Commercial Banks' Efficiency in Bangladesh: Does Crisis Matter? Journal of Asian Finance, Economics and Business, 4(3), 19-26. http://dx.doi.org/10.13106/jafeb.2017.vol4.no3.19

Bian, X. L., \& Chen, X. B. (2009). Analysis of operating efficiency of China's securities firms based on DEA Method. New Finance, 3, 10-13.

Chen, R., \& Zheng, Z. L. (2008). Unbiased estimation, price discovery and futures market efficiency: Futures Prices and Spot Prices. System Engineering Theory and Practice, 8, 2-11.

Cooper, W. W., Gu, B., \& Li, S. (2001). Comparisons and evaluations of alternative approaches to the treatment of congestion in DEA. European Journal of Operational Research, 1, 62-74.

Feng, F. Y. (2019). Analysis on the influence of Internet finance on the technical efficiency of commercial Banks in China. Nanjing Normal University. Retrieved from https://xueshu.baidu.com/usercenter/paper/show?paperid= 6846fa80df21261ec0e4df557ec3c92a\&site=xueshu_se\&hitart icle $=1$

Fukuyama, H., \& Weber, W. L (1999). The efficiency and productivity of Japanese securities firms. Japan \& the World Economy, 11, 115-133.

Guan, Z. C. (2009). The application of SFA in Technical Efficiency Evaluation of Research Institutes. Scientific Research Management, 6(November), 152-155.

Gui, J. L., \& Zhang, L. Q. (2016). Research on input-output efficiency of R\&D. Journal of Shunde Polytechnic, 4, 33-38.

Jiang, Y. (2018). Found Price: Futures and Financial Derivatives. Beijing, China: CITIC Publishing Group.

Le, T. T. D. (2020). Determinants of Retail Banking Efficiency: A Case of Vietcombank Branches in the Mekong-Delta Region. Journal of Asian Finance, Economics and Business, 7(7), 439451. https://doi.org/10.13106/jafeb.2020.vol7.no7.439

Lee, J. W. (2020). CSR Impact on the Firm Market Value: Evidence from Tour and Travel Companies Listed on Chinese Stock Markets. Journal of Asian Finance, Economics and Business, 7(7),159-167.https://doi.org/10.13106/jafeb.2020.vol7.no7.159

Lee, J. W. (2020). Lagged Effects of R\&D Investment on Corporate Market Value: Evidence from Manufacturing Firms Listed in Chinese Stock Markets. Journal of Asian Finance, Economics and Business, 7(8), 69-76. https://doi.org/10.13106/jafeb.2020. vol7.no8.069

Li, G. P., Cao, B., \& Xu, W. (2004). Stock futures investment strategy which based on forecast. Shopping Mall Modernization, 14, 6364. DOI: 10.3969/j.issn.1006-3102.2004.23.034

Li, H. G. (1998). On the investment function and investment strategy of futures market. Journal of Heilongjiang Finance and Economics, 2, 7-12.

Luo, H., \& Guo, Z. (2011). Efficiency evaluation of universities of "the 985 project" in China based on DEA superefficiency model-an improved model integrating evaluation of Chinese universities and ranking of online universities. Journal of Graduate Education, 6, 48-55.

Luo, X. G. (2015). Research on the application of investment strategy of China futures private equity fund. University of Guangxi. DOI:10.7666/d.Y3086560

Ni, Y. (2016). Study on evaluation of university science and technology efficiency based on lagging non-radial superefficiency DEA. Management Review, 11, 85-94.

Ouyang, R. H. (2005). Futures Market Efficiency: An Analytical Framework for Institutional Economics. Economic Research in Nankai, 3, 22-27. Doi: 10.3969/j.issn.1001-4691.2005.03.004

Sathye, M. (2003). Efficiency of banks in a developing economy: The case of India. European Journal of Operational Research, 148(3), 662-671.

Wang, X. F., \& Cheng, K. S. (2009). An Analysis on Dynamic Efficiency of China Securities Industry. Industrial Economics Research, 2, 53-58. DOI: 10.3969/j.issn.16719301.2009.02.007 
Yan, P., Ma, X. X., \& Wang, H. T. (2016). Evaluation of scientific research efficiency in Chinese universities-Analysis based on DEA and Malmquist Index. Finance and Accounting Monthly, $32,5-11$.

Yang, Z. W., \& Yang, Y. J. (2011). Analysis on the efficiency of the input and output for science and technology of Chinese tea research institutes. Journal of Tea Science, 31(6), 561-566.

Yao, S. J., Feng, G. F., \& Han, Z. W. (2005). Empirical Analysis of Insurance Efficiency in China. Economic Research, 7, 56-65.

Yuan, W. R. (2006). Stock futures investment strategy based on prediction theory and method. Journal of Gansu Social Science, 5,148-152. DOI: 10.3969/j.issn.1003-3637.2006.05.041

Zhang, Q. H., \& Zhang, H. (2015). Evaluation and Analysis of Science and Technology Innovation Efficiency in Provincial Colleges and Universities Based on DEA Method. Technology and Innovation Management, 3, 237-242. DOI: 0.14090/j.cnki. jscx.2015.0304

Zhang, Q., Zhang, S. H., \& Luo, X. (2013). Valuation of Scientific Research Performance in Local Universities Based on DEA Method. Journal of Shanxi Agricultural University Social Sciences, 10, 1061-1066.

Zhang, Q., Zhang, S. Y., \& Luo, L. (2013). Evaluation of Scientific Research Performance in Local Universities Based on DEA Method. Journal of Shanxi Agricultural University: Social Science Edition, 10, 1062-1066.

Zhang, W. D., Zhang, S. H., \& Luo, X. M. (2006). Technological progress, inefficiency, and productivity growth in the US securities industry. 1980-2000. Journal of Business Research, 59(5), 589-594. DOI: 10.1016/j.jbusres.2005.10.011 